\title{
KOMPUTERYZACJA GROMADZENIA ZBIORÓW A ZINTEGROWANY SYSTEM BIBLIOTECZNY. DOŚWIADCZENIA BIBLIOTEKI JAGIELLOŃSKIEJ
}

\author{
Ewa Dąbrowska \\ Biblioteka Jagiellońska
}

Gromadzenie zbiorów, komputeryzacja, VTLS, AFAS, moduł gromadzenia VIRTUA, systemy zintegrowane, ewidencja zbiorów

W ciaggu ostatnich dwudziestu lat rozwój technik informatycznych sprawił, że w polskich bibliotekach zaszły rewolucyjne zmiany, przekształcające je w biblioteki elektroniczne i hybrydowe. Systemy biblioteczne, obejmujące całość lub większość procesów bibliotecznych, wpłynęły znacząco na organizację i charakter pracy bibliotekarza, dla którego jeszcze niedawno podstawowym narzędziem pracy był ołówek i fiszka. Biblioteki mogą wybierać między systemami wyspecjalizowanymi, spełniającymi tylko jedną funkcję, systemami złożonymi $z$ wielu wyspecjalizowanych podsystemów oraz systemami zintegrowanymi. Za system zintegrowany uważa się system wielofunkcyjny, obejmujący wszystkie lub większość funkcji bibliotecznych, w którym pracuje się na jednej wspólnej bazie danych ${ }^{1}$. Jego główną idea jest wykorzystywanie informacji jednego podsystemu przy obsłudze drugiego ${ }^{2}$, a zwłaszcza stopniowe rozbudowywanie i wzbogacanie opisu bibliograficznego zapoczątkowanego lub skopiowanego z dostępnego źródła już na etapie gromadzenia zbiorów3 ${ }^{3}$. Przystępując do komputeryzacji Biblioteka Jagiellońska (dalej BJ), wzięła pod uwagę taki właśnie typ systemu i organizacji pracy. W artykule chciałabym zatem przedstawić przebieg komputeryzacji procesów gromadzenia zbiorów w BJ w odniesieniu do wdrażanego tu systemu komputerowego i pokazać, jak wyglądało w praktyce zetknięcie idei systemu zintegrowanego z rzeczywistością biblioteczną.

Przebieg komputeryzacji w polskich bibliotekach jest często, niestety, słabo udokumentowany, przez co staje się trudny do zrekonstruowania ${ }^{4}$. Tym bardziej warto przeanalizować historię tego, z różnych powodów skomplikowanego i jak okazało się, w praktyce wciąż jeszcze - w zakresie gromadzenia zbiorów w BJ - niezakończonego procesu. Podjęłam się tego jako nie tylko obserwator, ale aktywny uczestnik wydarzeń, które znacząco zmieniły oblicze biblioteki.

${ }^{1}$ A. Jacquesson: Automatyzacja bibliotek: zarys historyczny, strategia, perspektywy. Warszawa 1999, s. 288.

${ }^{2}$ Ibidem, s. 81. Autor zauważa, że filozofia ZSB przeważała do lat 80. XX w., a ponieważ nie zaspokajały one wszystkich potrzeb danej biblioteki, rosnąć zaczęło zainteresowanie systemami złożonymi.

${ }^{3}$ A. Radwański: Jak komputeryzować bibliotekę: poradnik. Warszawa 2000, s. 60.

${ }^{4}$ Ibidem, s. 104. 


\section{Pierwsze kroki w świat komputerów}

Wprawdzie pierwsze polskie próby komputeryzacji czy też mechanizacji sięgaja lat 60. XX w., dotyczyły jednak głównie zastosowań informacyjnych oraz bibliograficznych. W latach 70 . zaczęto komputeryzować czynności biblioteczne, przerwał to jednak kryzys polityczno-gospodarczy lat $80 .{ }^{5}$. Tymczasem w Wielkiej Brytanii już w połowie lat 80 . ubiegłego wieku w $85 \%$ ogłoszeń dotyczących pracy $w$ bibliotece koniecznym warunkiem było doświadczenie $w$ pracy $z$ komputerem ${ }^{6}$.

Sytuację w Polsce zmieniło upowszechnienie się mikrokomputerów, na przełomie lat 80 . i 90 . pojawiły się na biurkach bibliotekarzy, co pozwoliło na oswojenie się z nową techniką przed przystapieniem do planowej komputeryzacji biblioteki. Komputery zaczęto stosować w bieżącej pracy, od pisania korespondencji poczynając, do zakładania różnych baz danych. Bazy te były prowadzone równolegle do kartotek fiszkowych, do których drukowano karty z programu, nie potrafiono bowiem rozstać się od razu z tradycyjnym warsztatem pracy. Należy przyznać też, że początkowo były traktowane jako ciekawostka, coś, co można pokazać gościom, by się pochwalić nowoczesnością.

W Oddziale Gromadzenia i Uzupełniania Zbiorów (dalej OGR) powstała, w programie Micro CDS/ISIS, kartoteka książek zagranicznych, pochodzących z kupna, wymiany i darów. Sekcja Wymiany zaczęła wykorzystywać program, napisany pierwotnie dla księgarni, do obsługi wysyłki publikacji uczelnianych do kontrahentów w kraju i za granicą. Sekcję Kupna w sprawach związanych z rozliczeniami wydatków wspomagał arkusz kalkulacyjny Lotus 123 . Dla wszystkich ułatwieniem w prowadzeniu korespondencji stały się edytory tekstu, a zakupiona baza danych dostarczała nie tylko Sekcji Egzemplarza Obowiązkowego informacji o nowo powstałych firmach wydawniczych. Wkrótce też powszechnie wykorzystywanym narzędziem stał się internet i poczta e-mail.

\section{Gromadzenie po podjęciu decyzji o komputeryzacji BJ}

Gdy na początku lat dziewięćdziesiątych zapadła decyzja o zakupie i wdrożeniu zintegrowanego systemu bibliotecznego VTLS, dla dyrekcji Biblioteki jasne było, że system musi objąć również gromadzenie zbiorów, gdzie miał powstawać zaczątek opisu bibliograficznego pozyskiwanych w różny sposób publikacji. Ówczesna wersja tego systemu nie zawierała jednak w pełni zintegrowanego modułu wspomagającego proces gromadzenia, oferowany był natomiast program o nazwie AFAS [Acquisitions ans Fund Accounting System]?, którego najważniejsze funkcje to kontrola realizacji zamówień oraz prowadzenie księgowości. BJ jako jedyna biblioteka w Polsce zdecydowała się na jego na-

${ }^{5}$ E. Ścibor: Zarys historii mechanizacji i automatyzacji bibliotek w Polsce. W: A. Jacquesson: Automatyzacja bibliotek..., op. cit., s. 12-13.

${ }^{6}$ P. F. Burton: Technologia informacyjna $i$ jej wpływ na służby biblioteczno-informacyjne. W: Automatyzacja bibliotek: wybór materiałów z konferencji "Automatyzacja bibliotek" Wroclaw, 11-13 grudnia 1992. Wrocław 1993, s. 17.

7 Dokładne omówienie programu zob. E. Dąbrowska: AFAS - system obsługi zamówień i księgowania wydatków w ocenie użytkownika. "Bibliotekarz" 1998, nr 3, s. 11-14. 
bycie, wkrótce przystapiono więc do przygotowań niezbędnych do wdrożenia. Oprócz zapoznania się z samym systemem przez pracowników i przetłumaczenia dokumentacji oraz komend w programie, należało opracować procedury pracy w nim i przygotować niezbędne na starcie wzory typowej korespondencji, system kont księgowych, kartotekę walut oraz bibliotek instytutowych. Zasilono także bazę dostawców danymi wgranymi z zakupionej bazy wydawców polskich oraz adresami kontrahentów wymiany z programu wymiany.

Zdecydowano, że AFAS obejmie całość procedur związanych z zakupami wydawnictw zwartych, zbiorów specjalnych oraz niektórych wydawnictw ciągłych ${ }^{8}$, scali wszystkie kartoteki zamówień i przybytków oraz kartoteki kontrahentów wymiany, dostawców sekcji kupna, darczyńców i wydawców. Już samo to znacznie ułatwiło i uprościło pracę, gdyż dotąd w wielu wypadkach, sprawdzając jeden tytuł, należało przeszukać kilka kartotek. Zaprzestano oczywiście prowadzenia ich tradycyjnych odpowiedników. Czasopisma prowadzono dalej na kartach kontynuacyjnych, gdyż AFAS nie oferował tu optymalnego rozwiązania. Powoli natomiast, $w$ miarę opracowywania kolejnych tytułów ciągłych przez Oddział Opracowania Czasopism, przechodzono do rejestrowania wpływu czasopism w rekordzie zasobu w katalogu online.

Niestety, AFAS nie zawierał funkcji rejestru przybytku w rozumieniu obowiazujących w BJ przepisów o wstępnej ewidencji wpływów, stąd był on prowadzony dalej $w$ sposób tradycyjny. Brakowało też $w$ tym programie możliwości obsługi wysyłki wydawnictw w ramach wymiany i gospodarki dubletami i drukami zbędnymi. Był zatem rozwiązaniem cząstkowym, choć już w tym zakresie, który oferował, znacząco poprawiał jakość pracy, a producent obiecywał w przyszłości doskonalsze rozwiązania.

Komputeryzacja biblioteki - a więc zmiana narzędzi i systemu pracy - to dobry moment do rozważenia, co można lub należy zmienić w organizacji pracy. $\mathrm{Na}$ zebraniach toczono dyskusje nad ewentualnymi usprawnieniami, nad tym, z czego można zrezygnować, a z czego nie. Omawiano znane z literatury fachowej i przykładów innych bibliotek przypadki łączenia działów i funkcji, rozważano, czy i na ile może to poprawić jakość pracy. Zdarzały się postawy niechętne wobec wprowadzanych zmian, dla niektórych problemem była konieczność przełamania utartych schematów myślenia, wytrącenie z wygodnego toru dawno wypracowanych metod pracy. Przeważała jednak postawa jeśli nie entuzjastyczna, to przynajmniej aprobująca. Nie brakowało pomysłów dobrych, ale przedwczesnych, nie do zrealizowania w ówczesnych warunkach, co pokazały następne lata. Ostatecznie przystapiono do pracy w systemie bez większych zmian w organizacji pracy, modyfikacji uległ natomiast jej charakter. Zmiany następowały stopniowo, jako logiczna konsekwencja przemian następujących w bibliotekarstwie pod wpływem postępującej informatyzacji, a posunięcia, które wydawały się na początku nie do przyjęcia, z czasem okazywały się najlepszym wyjściem.

${ }^{8}$ Dotyczyło to wówczas przede wszystkim czasopism zakupywanych poza główną prenumerata, m.in. w Ośrodku Rozpowszechniania Wydawnictw Naukowych PAN, figurujących na jednym rachunku razem z wydawnictwami zwartymi. 


\section{Pół kroku w kierunku systemu zintegrowanego}

AFAS nie był integralną częścią systemu VTLS, ale odrębnym programem. Dawał do wyboru dwie możliwości pracy: zupełnie samodzielnej, w oderwaniu od całości systemu, albo we współpracy z nim. Biblioteka Jagiellońska zdecydowała się na ten drugi model. Współpraca ta polegała przede wszystkim na kopiowaniu z katalogu online do AFAS-u danych bibliograficznych, wykorzystywanych następnie przy zamawianiu lub rejestrowaniu wpływających książek. Siła rzeczy pracownicy OGR musieli najpierw te dane bibliograficzne samodzielnie do katalogu wprowadzić, co sprowadzało się do zapisu w kilku polach formatu USMARC tytułu i odpowiedzialności, adresu wydawniczego, wydania i ISBN. Były to informacje wystarczające do zidentyfikowania książki na poziomie gromadzenia. Zarejestrowana w ten sposób książka funkcjonowała w katalogu online ze statusem „zamówiona”, a jej opis był korygowany i uzupełniany przez Oddział Opracowania, kiedy już tam dotarła. Problem stwarzały opisy tytułów, które bardzo długo nie wpływały, a niektóre zamówienia nigdy nie zostały zrealizowane. W opinii wielu "zaśmiecało” to bazę i obniżało wartość naszego katalogu.

Dane skopiowane do AFAS-u wykorzystywano do tworzenia zamówien, wiążąc je z rekordami dostawców, kont księgowych, walut, realizacji, itp. $W$ ten sposób rejestrowano nie tylko rzeczywiste zamówienia, ale również wpływające bez wcześniejszego zamówienia publikacje ze wszystkich źródeł. Miało to zapewnić szybką informację o zasobie bibliotecznym w celu jego bieżącego uzupełniania oraz uniknięcia dubletów. Było to zajęcie czasochłonne, tym bardziej, że wpływy do Biblioteki wzrastały, ale wówczas nie wyobrażano sobie, że można by przekazywać książki do opracowania formalnego bez zarejestrowania danych bibliograficznych na etapie gromadzenia zbiorów, jak to wówczas sugerowali konsultanci z firmy VTLS.

Istniała także możliwość przekazywania z AFAS-u do VTLS-u informacji o stanie realizacji zamówienia oraz danych adresowych z kartoteki dostawców AFAS do modułu obsługi wpływu czasopism VTLS w celu urgowania czasopism. Występowały przy tym jednak trudności techniczne, które ostatecznie wpłynęły na zaniechanie tych czynności.

Taki był tryb pracy z książka. Wpływ czasopism do czasu ich opracowania w katalogu online rejestrowano na tradycyjnych kartach kontynuacyjnych, a wpływające zbiory specjalne rejestrowano tylko w AFAS-ie.

Sekcja Egzemplarza Obowiązkowego wykorzystywała elektroniczną wersję Przewodnika Bibliograficznego, z której kopiowano do AFAS-u opisy książek, wykorzystywane potem do upominania się o nie u wydawców. Przez jakiś czas praca EO w tym zakresie była jeszcze bardziej uproszczona, gdyż zautomatyzowano monitowanie poprzez mechaniczne porównywanie zawartości Przewodnika Bibliograficznego z zawartością katalogu online, a upomnienia wysyłano na wyselekcjonowane $w$ ten sposób opisy. Jednak nie była to optymalna metoda, gdyż $w$ ten sposób przy urgowaniu pomijano książki będące w posiadaniu bibliotek instytutowych Uniwersytetu Jagiellońskiego, a których nie miała Biblioteka Jagiellońska. Komputerowy katalog jest bowiem katalogiem centralnym Uniwersytetu Jagiellońskiego, obejmującym również zbiory biblio- 
tek instytutowych. Po jakimś czasie zrezygnowano więc $z$ tej metody $w$ trosce o kompletność zbiorów BJ.

Istotnym problemem był brak możliwości nadawania lub choćby notowania numeru akcesji w AFAS-ie. W Bibliotece Jagiellońskiej prowadzi się zbiorczą ewidencję wpływu, obejmującą wszystkie otrzymywane materiały, niezależnie od tego, czy wejda następnie do zbiorów. W dalszym ciągu prowadzono więc rejestr przybytków w sposób tradycyjny, pisany ręcznie, a nadany $w$ ten sposób numer akcesji wpisywano w polu notatek przy rekordzie zamówienia. Prowadzono nawet dyskusje, czy numer akcesji jest w ogóle potrzebny, co się odzwierciedliło tym, że przez kilka pierwszych lat w katalogu online nie umieszczano go w żadnym polu opisu bibliograficznego czy rekordu egzemplarza. Praktyka wykazała, że w bibliotece takiej jak BJ akcesja, świadcząca o proweniencji książki czy innego materiału bibliotecznego, jest czymś ważnym.

AFAS nie zaspokajał także wymagań Sekcji Wymiany. Do jej zadań należy nie tylko zamawianie i przyjmowanie książek, ale i wysyłanie wydawnictw uczelnianych i innych do kontrahentów, czego AFAS nie obsługiwal. W dalszym ciągu więc posługiwano się do tego celu programem, stworzonym w zasadzie na potrzeby księgarni, który był w stanie tworzyć listy wysyłkowe do kontrahentów mających u nas stałe zamówienia na wydawnictwa ciągle. Nie jest to tylko problem spotykany w produktach firmy VTLS, moduł gromadzenia systemu PROLIB również nie oferuje takiej funkcji ${ }^{9}$. Idealna byłaby sytuacja, gdyby całość prac wymiany obejmował jeden system, potrafiący jeszcze dokonać bilansu publikacji wysyłanych w stosunku do otrzymywanych.

Tak więc AFAS tylko częściowo zaspokajał potrzeby OGR, pozostawiając poza swoim zakresem wiele działań, przy których musiano posiłkować się innymi programami, nie był też w stanie dostarczyć wymaganych od OGR danych statystycznych. Dane bibliograficzne, kopiowane $z$ katalogu online, mogły być w AFAS-ie modyfikowane lub usuwane, co nie wpływało na stan danych w katalogu.

\section{I krok wstecz}

Po dwóch latach zdecydowano się na zaprzestanie wstępnego katalogowania książek przez pracowników OGR w katalogu online, ponieważ było to zbyt czasochłonne, a kłopotliwe dla oddziału opracowania, który argumentował, że łatwiej założyć nowy rekord bibliograficzny, niż poprawiać już istniejący ${ }^{10}$.

${ }^{9} \mathrm{~J}$. Dziak: Zastosowanie nowoczesnych technologii informacyjnych w procesie gromadzenia zbiorów na przykładzie biblioteki wyższej uczelni technicznej. W: Usługi-aplikacje - treści w gospodarce opartej na wiedzy. Pod red. D. Pietruch-Reizes i W. Babika. Warszawa 2004, s. 168-173; K. Żmigrodzka: Nowe formy pracy Oddziału Gromadzenia Zbiorów. W: Ewolucja procesów bibliotecznych na tle dziejów Biblioteki Głównej Akademii Ekonomicznej we Wrocławiu. Wroclaw 2007, s. 62-63.

${ }^{10} \mathrm{Nie}$ jest to tylko nasze doświadczenie - jak pisze Alain Jacquiesson w cytowanej wyżej książce, coraz rzadziej stosowanym rozwiązaniem jest ponowne wykorzystanie w procesie katalogowania opisów dokumentów opracowanych wstępnie przy okazji zamówienia, gdyż korekta takiego opisu trwa dłużej niż sporządzenie nowego. A. Jacquiesson: Automatyzacja..., op. cit., s. 85. Tym niemniej wiele bibliotek polskich przyjęło taką organizację pracy, łącząc przy tym często działy gromadzenia i opracowania formalnego druków zwartych. 
Zaczęto więc już ok. 1996 r. rejestrować książki tylko w AFAS-ie. Tymczasem gwałtownie wzrastająca liczba wpływających do biblioteki publikacji, zwłaszcza pochodzących z egzemplarza obowiązkowego, spowodowała duże kłopoty z bieżącym opracowaniem wpływających materiałów. Gdy w 1994 r. ze wszystkich źródeł wpływu razem otrzymaliśmy ok. 45 tys. woluminów zwartych i ciągłych, to $w 1998$ r. było tych woluminów prawie 63 tys., przy czym nie wzrosła liczba pracowników OGR ${ }^{11}$.

Należy pamiętać, że BJ jest ustawowo zobowiązana do wieczystego archiwizowania jednego $z$ dwu otrzymywanych egzemplarzy obowiązkowych, nie może więc, jak inne biblioteki, prowadzić selekcji otrzymywanych bezpłatnie od wydawców publikacji i wprowadzać do zbiorów tylko interesujące pozycje. Choć nie wszyscy wydawcy przysyłają egzemplarz obowiązkowy, to i tak jego ilość wzrasta z roku na rok. Ale nie tylko $w$ tym odzwierciedla się uznaniowa rola BJ jako drugiej biblioteki narodowej $w$ kraju: specjalizuje się ona $w$ gromadzeniu rękopisów, starodruków, grafik, zbiorów kartograficznych, gdzie wprawdzie decyzja o pozyskaniu do zbiorów należy już do właściwych oddziałów zbiorów specjalnych, ale samo nabycie musi znaleźć odzwierciedlenie w dokumentacji OGR, a jako biblioteka uniwersytecka ma na celu zaspokajanie potrzeb czytelniczych i informacyjnych środowiska akademickiego.

Wskutek znaczącego wzrostu wpływów w 1998 r. podjęto decyzję o całkowitym zaprzestaniu wstępnego katalogowania na etapie gromadzenia zbiorów. Odtąd AFAS był wykorzystywany przez Sekcję Kupna, która za jego pomocą prowadziła zamówienia i rejestrowała rachunki, przez Sekcję Egzemplarza Obowiązkowego do monitowania wydawców o niedostarczone zgodnie z przepisami książki, a przez Sekcję Wymiany i Darów głównie do prowadzenia kartoteki ofiarodawców i kontrahentów.

Od tej pory książki, objęte tylko wstępną, zbiorczą ewidencją wpływu w OGR, kierowane są do Oddziału Opracowania, a katalog online stał się głównym źródłem informacji o nabytkach. W polu 910 rekordu bibliograficznego umieszczany jest nadany przez OGR numer akcesji, dzięki czemu jeszcze przed utworzeniem rekordów egzemplarza wiadomo, że dana książka jest własnością BJ, a nie jednej z bibliotek instytutowych. W wypadkach, które tego wymagają, można wspierać się dokumentacją związaną z rejestrem przybytków, m.in. wykazami otrzymywanych publikacji.

Producent oprogramowania nie przykładał się zbytnio do rozwijania AFAS-u, w którym przez wszystkie lata użytkowania były funkcje "niedostępne w tej wersji oprogramowania", sposób szeregowania znaków pozostawiał wiele do życzenia (np. polskie znaki szeregowane po alfabecie łacińskim), a opcja archiwizacji danych obejmowała tylko zakupy i dary. Dla egzemplarza obowiązkowego nie przewidziano nawet odpowiedniego typu zamówienia, użytkowano więc "federal depository", co wymagało podawania fikcyjnego w tym wypadku konta, z którego zamówienie miałoby być opłacone.

Pracowano już nad systemem Virtua, która miała być doskonałym produktem docelowym. Jednak testowanie modułu dla gromadzenia przeprowadzone w kilku polskich bibliotekach ok. 2004 r. dowiodło, że w dalszym ciągu nie

${ }^{11}$ Rok 2009 przyniósł ponad 80 tys. woluminów zwartych i ciagłych z samego tylko egzemplarza obowiązkowego przy tej samej obsadzie oddziału. 
zaspokaja on ich potrzeb, skutkiem czego nie został w Polsce wdrożony ${ }^{12}$. W BJ rozpoczęto zatem w 2007 r. prace nad własnym programem dla OGR, na razie obsługujacym tylko jeden, ale najpilniejszy wycinek pracy - upominanie się o książki niedostarczone w ramach egzemplarza obowiązkowego. Powstał program intuicyjny w obsłudze, przyjazny pracownikowi. Obejmuje kartotekę wydawców, do której można przenieść dane adresowe zebrane w AFAS-ie, kartotekę opisów bibliograficznych, zamówień, upomnień i ich wydruków, oraz dziennik korespondencji rejestrujący wychodzące pisma, daje dostęp do stron www i poczty e-mail z rekordu dostawcy oraz szersze niż w AFAS-ie możliwości przeszukiwania rekordów ${ }^{13}$. Pracę usprawnia system podpowiedzi $w$ trakcie wypełniania pól i łatwy mechanizm wprowadzania danych kolejnych tomów serii monograficznych. Od razu dało się zauważyć, że praca w tym programie jest nie tylko bardzo wygodna, ale i szybka. Jest to program „szyty na miarę", który może być na bieżąco uzupełniany i rozbudowywany zgodnie z potrzebami. Natomiast programy czy też moduły większych systemów oferowane na rynku wykazują zwykle w sprawach związanych z gromadzeniem zbiorów braki, z powodu których biblioteki muszą się wspierać dodatkowymi oprogramowaniami w procesie gromadzenia zbiorów.

\section{Czy gromadzenie zbiorów musi być objęte zintegrowanym systemem ogólnobibliotecznym?}

Mówiąc o zintegrowanym systemie bibliotecznym, mamy na myśli system obejmujący całość procesów bibliotecznych, poczynając od gromadzenia zbiorów. System, w którym opis publikacji rejestrowanej przez oddział gromadzenia jest na następnych etapach opracowania rozbudowywany, a zarówno bibliotekarz, jak i czytelnik ma dostęp do informacji nie tylko o nabytkach od momentu ich wpływu, ale i o pozycjach dopiero zamawianych do zbiorów.

W kontekście uwarunkowań wewnętrznych, jakimi są cele i zadania Oddziału Gromadzenia Zbiorów, a także możliwości oferowanych przez funkcjonujący w Bibliotece system komputerowy, oraz zewnętrznych, czyli w naszym przypadku - współpracy z NUKAT, powstaje pytanie, czy objęcie procesów gromadzenia zbiorów BJ w ramach jednego, ogólnobibliotecznego systemu zintegrowanego jest konieczne i w ogóle możliwe.

${ }^{12}$ Zob. m.in: J. Ratkowska: Trójmiejski Zespół Biblioteczny jako przykład współpracy srodowisk naukowych w zakresie komputeryzacji bibliotek: wady, zalety, propozycje rozwiązań normalizacyjnych. W: Elektroniczny wizerunek biblioteki. Pod red. Mai Wojciechowskiej. Gdańsk 2008, s. 201; P. Korobczak, P. Domino: Baza danych Oddziału Gromadzenia Biblioteki Uniwersyteckiej we Wrocławiu. W: Komputeryzacja Biblioteki Uniwersyteckiej we Wroctawiu - dziesięć lat doświadczeń. [dokument elektroniczny]. Praca zbior. pod red. Grażyny Piotrowicz. Wrocław 2006, s. 95-114; K. Mojejko-Kotlińska: Bazy danych w automatyzacji funkcji bibliotecznych w BG UMCS w Lublinie. W: Infobazy '2002 - bazy danych dla nauki: materiały z konferencji, Gdańsk, 24 czerwca - 26 czerwca 2002 r. [pod red. Antoniego Nowakowskiego] Gdańsk 2002, s. 183-188.

${ }^{13}$ W AFAS-ie jedynym elementem opisu bibliograficznego dostępnym do wyszukiwania był tytuł. 
Moduł gromadzenia Virtua, będący częścią zintegrowanego systemu, dalej jest przede wszystkim narzędziem do zamawiania publikacji i rozliczania wydatków, a tymczasem główne źródło wpływu w BJ to egzemplarz obowiązkowy, wielokrotnie przewyższający wszystkie inne źródła wpływu razem wzięte. Znamienne jest, że żadna z bibliotek w Polsce użytkujących system firmy VTLS nie wprowadziła, poza Biblioteką Jagiellońską, produktów tej firmy obsługujących gromadzenie zbiorów, ponieważ w ocenie tych bibliotek nie były zadowalające. Potrzebne były inne wspomagające programy, a pewne czynności, które mogły być skomputeryzowane, wykonywano dalej tradycyjnie.

AFAS nie przewidywał nadawania numeru akcesji. Producent oprogramowania obiecywał wprowadzenie akcesji w module Virtua, jak jednak mogliśmy się przekonać na pokazie podczas spotkania użytkowników VTLS w Gdańsku w czerwcu 2010 r., polega to na dodaniu jednego pola w rekordzie egzemplarza, w którym można wpisać nadana już wcześniej na daną pozycję akcesję ${ }^{14}$ !

Kolejnym problemem jest to, że system zintegrowany zakłada gromadzenie metadanych już na etapie gromadzenia zbiorów, tymczasem w warunkach BJ byłoby to ich tworzenie, a więc katalogowanie. W literaturze często można napotkać koncepcje zakładające możliwość ściągania opisów bibliograficznych $z$ baz danych dostawców ${ }^{15}$ Czy z ogólnokrajowych serwisów księgarskich ${ }^{16}$ już na etapie gromadzenia zbiorów w momencie zamawiania publikacji, co w efekcie miało doprowadzić do zaniku oddziałów opracowania formalnego ${ }^{17}$. Jak do tej pory polscy wydawcy nie potrafili porozumieć się w sprawie centralnego katalogu składowego ani nie widzą takiej potrzeby, o czym można przeczytać w relacjach z zebrań Polskiej Izby Książki ${ }^{18}$. Bardziej realne jest pobieranie danych $z$ bibliotecznego katalogu centralnego takiego jak NUKAT lub z Biblioteki Narodowej. Jest to jednak rozwiązanie dla mniejszych bibliotek, nie o tak rozbudowanych i różnorodnych zbiorach jak BJ, która stoi na czele bibliotek intensywnie katalogujących $w$ NUKAT ${ }^{19}$. W ogóle trudno by było znaleźć kompletne źródło danych bibliograficznych, z którego pracownicy OGR mogliby czerpać opisy publikacji, wpływają tu bowiem książki z całego świata, zarówno całkiem nowe, jak i bardzo stare. Lata temu zrezygnowano z katalogowania wszystkich publikacji na poziomie OGR w katalogu online $w$ trosce o zapewnienie szybkiej informacji - nie tylko czytelnikowi, ale i bibliotekarzowi, co jest możliwe dzięki naciskowi położonemu na bieżące katalogowanie wpływów przez oddział opracowania. Także dla innych bibliotek - instytutowych,

${ }^{14}$ Wynika to zapewne z faktu, że jest to system amerykański, utworzony pierwotnie dla tamtejszej biblioteki, a biblioteki amerykańskie uważają księgi i rejestry akcesyjne za zbędne. Zob. Encyklopedia Wiedzy o Książce. Wrocław 1971, s. 19.

${ }^{15}$ P. F. Burton: Wdrażanie technologii informacyjnej: uwagi ogólne. W: Automatyzacja bibliotek: wybór materiałów z konferencji „Automatyzacja bibliotek” Wrocław, 11-13 grudnia 1992. Wrocław 1993, s.11.

${ }^{16}$ A. Radwański: Jak komputeryzować..., op. cit., s. 60.

${ }^{17}$ J. Maj, M. Nahotko, W. Szczęch: Zastosowanie komputera w bibliotece. Warszawa 1996, s. 11.

${ }^{18}$ Odpowiedź IKP na decyzję PIK w sprawie Polskiego Katalogu Składowego Ksiażki. [online]. [dostęp: 9.11.2010]. Dostępny w World Wide Web: <http://www.ksiazka.net.pl/?i$\mathrm{d}=$ archiwum09\&uid=13202>

${ }^{19}$ E. Chrzan: Komputeryzacja bibliotek naukowych w Polsce: ewolucja świadomości. W: Elektroniczny wizerunek biblioteki. Pod red. M. Wojciechowskiej. Gdańsk 2008, s. 190. 
czy działających w tym samym mieście - sygnał, że dana książka znajduje się w BJ, pozwala zaoszczędzić na zakupie, zwłaszcza gdy chodzi o drogą książkę zagraniczną.

Natomiast podjęcie katalogowania na etapie zamawiania budzi poważne wątpliwości w kontekście współpracy z katalogiem centralnym NUKAT. Dane bibliograficzne wykorzystywane przy zamawianiu są czasami niepełne lub błędne, brane z folderów, katalogów i internetowych stron wydawców, z reklam w czasopismach, $z$ dezyderatów czytelników. Problemem są też pozostające w katalogu opisy bibliograficzne niezrealizowanych zamówień, których usuwanie nie byłoby właściwe, gdyż stanowią informację dla OGR, że podejmowano działania w celu sprowadzenia danej pozycji, co okazało się niemożliwe na przykład z powodu wyczerpania nakładu.

Należy pamiętać o tym, że zadaniem OGR jest ciągłe dbanie o pozyskiwanie materiałów do zbiorów, uzupełnianie posiadanego zasobu i zdobywanie nowości z różnych źródeł. Pracownik OGR powinien koncentrować się na publikacjach, których nie ma w bibliotece, a więc potrafić dotrzeć do informacji o nich oraz postarać się je sprowadzić (darmowo lub odpłatnie), przeprowadzić selekcję wpływających darów czy publikacji otrzymanych w ramach wymiany zgodnie z profilem biblioteki i oczekiwaniami czytelników. Rejestrowanie otrzymywanych materiałów to efekt końcowy tej pracy i nie powinno zajmować zbyt dużo czasu. Rozwiązaniem może być łączenie działów gromadzenia i opracowania, jak to miało miejsce w niektórych bibliotekach, pytanie jednak, na ile było to faktyczne połączenie struktur i ich funkcji, a na ile zabieg formalny, zachowujący w obrębie działu podział na odrębne jednostki gromadzenia i opracowania. Nie jest to jednak jedyne możliwe wyjście. Naszym zdaniem, wypracowany przez nas $w$ trakcie lat obserwacji i doświadczeń system pracy, w którym OGR koncentruje swoje wysiłki na uzupełnianiu zbiorów, a otrzymywane publikacje, po nadaniu numeru akcesji, kierowane sa do oddziału opracowania i tam katalogowane, jest zadowalający, zarówno ze względu na potrzeby czytelników, jak i pracowników biblioteki.

Daleko jeszcze do pełnej komputeryzacji procesów gromadzenia zbiorów w BJ. Stosowany przez jakiś czas AFAS, choć nie w pełni satysfakcjonujący, znacząco zmienił komfort pracy, trudno jednak na trwałe zadowalać się taką sytuacją, ponosząc jeszcze dodatkowo koszty finansowe. Także obecnie oferowany moduł gromadzenia firmy VTLS nie jest w stanie spełnić naszych oczekiwań, bo choć jest częścią zintegrowanego systemu bibliotecznego, to w zakresie oferowanych funkcji nie odbiega wiele od AFAS-u. Mimo to sa biblioteki w Polsce rozważające obecnie jego wdrożenie. Aby uniknąć problemów związanych ze współkatalogowaniem w NUKAcie, Biblioteka Uniwersytetu Gdańskiego proponuje ukryć przed czytelnikiem rekordy bibliograficzne utworzone przez pracowników gromadzenia zbiorów na poziomie katalogu lokalnego, a po dotarciu książki do oddziału opracowania zastępować je w całości na podstawie numeru systemowego przez właściwe rekordy skopiowane z NUKAT-u. Nie będzie więc mowy w takim przypadku o dostarczaniu czytelnikowi informacji o książce już na etapie zamawiania, co uważane jest za jedną z zalet systemu zintegrowanego, choć często nie jest zbyt dobrze 
widziane przez samych bibliotekarzy ${ }^{20}$. Braknie w tym wypadku także drugiej cechy systemu zintegrowanego - stopniowego rozbudowywania i wzbogacania rekordu bibliograficznego zapoczątkowanego na etapie gromadzenia.

Przystępując do komputeryzacji procesów gromadzenia zbiorów w BJ funkcjonował pewien teoretyczny obraz tego, jak powinna ona przebiegać. Wychodzono z założenia, że już na etapie gromadzenia do katalogu online należy wprowadzać opisy bibliograficzne dla zamawianych i otrzymywanych publikacji, uzupełniane na następnych etapach drogi książki, zgodnie z preferowaną ogólnie ideą systemów zintegrowanych. Miało to zapobiec dublowaniu pracy przez oddział gromadzenia i oddział opracowania oraz dostarczyć czytelnikowi szybkiej informacji na temat już otrzymanych lub dopiero oczekiwanych przez Bibliotekę publikacji. Założenie to zostało jednak zweryfikowane przez praktykę. Z czasem zarzucono całkowicie wstępne katalogowanie otrzymywanych w darze, drogą wymiany czy w ramach egzemplarza obowiązkowego książek, nawet tylko na poziomie wewnętrznej bazy OGR, czyniąc to jedynie dla publikacji zamawianych, czy to $w$ drodze kupna, czy w którejś z darmowych form pozyskiwania zbiorów.

Komputeryzacja gromadzenia zbiorów w przypadku BJ nie ograniczyła się do jednorazowego zaimplementowania zakupionego oprogramowania, ale jest to żywy, wciąż trwający proces, w którym zmianom podlegają zarówno wykorzystywane narzędzia informatyczne, jak i sama praca, jej tryb i organizacja. Zmiany te wynikają z obserwacji i wniosków wynikających z bieżącej pracy oraz z uwarunkowań zewnętrznych, głównie z rozwijającej się w kraju elektronicznej infrastruktury informacyjnej. Nie przeprowadzano gruntownych zmian organizacyjnych w strukturze działów, rozwijano natomiast współpracę pomiędzy nimi w celu usprawnienia pracy i zapewnienia czytelnikowi jak najszybszej możliwości dotarcia do informacji. Wyeliminowano zbędne, a czasami powtarzające się w różnych działach czynności. Osoby zajmujące się gromadzeniem zbiorów koncentrują się na pozyskiwaniu nowości i uzupełnień, katalogowanie pozostawiając przeznaczonym do tego oddziałom opracowania formalnego. Dzięki temu liczba zatrudnionych przy gromadzeniu osób nie wzrosła mimo wielokrotnego wzrostu wpływu i zmiany jego charakteru, a wykorzystywane narzędzia informatyczne, choć niejednorodne i rozproszone, znacznie ułatwiają pracę. Prowadzone będą działania zmierzające do rozbudowy zapoczątkowanego tu własnego oprogramowania obsługującego procesy gromadzenia zbiorów, co spowodowane zostało niesatysfakcjonującymi propozycjami firmy VTLS. Na ten stan rzeczy wpływ miał szereg czynników, przede wszystkim specyficzna

${ }^{20}$ B. Grocholska: Status rekordu „odkryty” - czy warto pokazywać opis bibliograficzny na etapie zamawiania książki. W: II Seminarium: Gromadzenie zbiorów - sztuka wyboru: Wrocław, 23-24 czerwca 2005 r. EBIB Elektroniczny Biuletyn Informacyjny Bibliotekarzy 2005. Materiały konferencyjne nr 11. [online]. [dostęp: 9.11.2010]. Dostępny w World Wide Web: <http://ebib.oss.wroc.pl/matkonf/grom2/grocholska.php>. Na podstawie przeprowadzonej ankiety autorka stwierdza, że zaledwie $20 \%$ z przebadanych przez nią polskich bibliotek uwidacznia swoje plany zakupowe przed czytelnikami. 
sytuacja Biblioteki Jagiellońskiej, będącej biblioteką uniwersytecką, a jednocześnie pełniącej rolę biblioteki narodowej, co determinuje charakter i wielkość gromadzonych zbiorów. Obowiązek wieczystego archiwizowania egzemplarza obowiązkowego sprawia, że polityka gromadzenia skierowana jest nie tylko na potrzeby współczesnego, ale i przyszłego czytelnika, dla którego staramy się zachować całość polskiej produkcji wydawniczej jako świadectwo dorobku umysłowego i kulturalnego oraz dokument życia społecznego Polski.

\section{Summary}

The article describes the computerization process in the Library Collection and Completion Department (LCCD) of the Jagiellonian Library, regarding its integrated library system. The AFAS software for collection processes, offered by the VTLS Company at the beginning of the 90ties, and being used by the Jagiellonian Library as the only one in Poland, has not been satisfying, regardless its significant work improvement. However, a narrow range of functions resulted in the decision on creating an own software, instead of buying current collection module of Virtua. As one can observe, the LCCD does not have to register bibliographical data of incoming unordered volumes, but only those which are going to be ordered. Books incoming for free, after collective registration and accession, are passed at once to the Indexing Department. 